\title{
Energy Economics: A Benefit-Cost Consideration Of Corn-Based Ethanol And Bio-Fuel
}

D. Adrian Doss, University of West Alabama, USA

Stacy Troxel, Arkansas State University, USA

Bill Sumrall, Belhaven College-Memphis, USA

\begin{abstract}
This paper discusses salient characteristics of corn-based ethanol and bio-fuels. The discussions contained within this paper consider the historical and contemporary attributes of such corn-based ethanol and bio-fuels characteristics, global and domestic considerations, the production and generation of such fuels, the usefulness and applications of such fuels, various growth potentials and barriers, future potentials, and financial costs and benefits. Based on these discussions, conclusions are presented and various recommendations are offered.
\end{abstract}

Keywords: ethanol, corn, biofuel, bio-fuel, alternative energy, energy, energy economics, economics, fuel mix, fuel forecast, energy forecast

\section{INTRODUCTION}

ithin the context of recent history, the use of oil has satisfied both the domestic and global
requirements of liquid fuel (Dahl, 2004). According to the writings of Dahl (2004), these uses
encompass a myriad of domains. Examples of such domains include the transportation industry to the provision of electricity (Dahl, 2004). Dahl (2004) indicates that both global and domestic demands increased with technological advancements and changes that incorporated the use of such fuel (e.g., railroads changing from coal to oil as a fuel; introduction of automobiles, etc.), but various sources and supplies of oil were diminished (e.g., peak oil events). Despite the continuous demand for oil associated with the needs and wants of humans, oil is a limited resource (Sims, et. al, 2006; Dahl, 2004). Dahl (2004) indicates that the basic, conceptual fuel needs and wants of humans remain basically unchanged, but the energy sources from which the satisfaction of human requirements is derived change through time. Given its scope as a limited resource, the finite characteristic of oil necessitates the contemplation of alternative sources of energy.

Various, alternative forms of deriving energy exist. Such alternatives include corn-based ethanol and biofuels. Kheshgi, Prince, and Marland (2000) define ethanol as a "liquid transportation fuel" that may be integrated and used "either blended with gasoline or in the form of hydrated ethanol, in internal combustion engines." Plant organisms are used to derive corn-based ethanol and bio-fuels (Timmins, 2006). This notion is also presented by Dahl (2004), and is confirmed by Fulton (2005) with the observation that these alternatives are produced from "crops such as corn." A myriad of applications exist with respect to the consumption of such fuel alternatives. The writings of Fulton (2005) indicate that such uses include the purpose of transportation, and indicate that the use of ethanol may represent nearly five percent of global transport fuel consumption before the year 2010. Although this estimate of five percent may appear to be insignificant, Fulton (2005) indicates that no other alternative fuel entity has impacted the fuel market with such significance in nearly a century. Fulton (2005) also indicates that such alternative fuels are distributed within numerous nations and among "service stations worldwide" for use within automobiles. Further, the U.S. is the "second major producer" of world bio-fuels (Agricultural Market, 2006). Based on these observations, evidence is presented that suggests a demand for such fuel products exists. 


\section{DISCUSSION}

The two categories of bio-fuels, that are representative of renewable energy sources, are biodiesel and ethanol, and they may be "used either as pure fuels, or blended with gasoline and diesel (Agricultural Market, 2006)." Therefore, based on this observation and the aforementioned writings of Fulton (2005) and Gardner (2007), the technological application of bio-fuels is manifested significantly within the transportation domain. This significance is enhanced technologically because of the "Otto cycle" capacity of bio-fuel to serve as a "substitute for gasoline in spark ignition (SI) engines" with respect to engine modification and "combustion efficiency (Sims, et. al., 2006)."

An analytical consideration of bio-fuel also involves the method through which the fuel is produced and operates as an alternative source of energy. According to the writings of Kheshgi, Prince, and Marland (2000), this process involves a chemical origin in which the initial stages of the process involve the atmospheric sequestering of carbon dioxide $\left(\mathrm{CO}_{2}\right)$. Kheshgi, Prince, and Marland (2000) indicate that four primary stages exist within this process: 1) the stage of production via photosynthesis, 2) the stage of "conversion and processing," 3) the stage of delivering the converted product, and 4) the stage of "end use." Energy requirements of the process may be obtained from various sources or recursively through the process itself (Kheshgi, Prince, and Marland, 2000). The "end use" outputs of the process may be used for a variety of purposes including the production of fuels or the generation of electricity (Kheshgi, Prince, and Marland, 2000).

Kheshgi, Prince, and Marland (2000) also consider ethanol with respect to its production as a result of the fermentation process. Specifically, ethanol results from the fermentation of sugar and starch (Kheshgi, Prince, and Marland, 2000). Kheshgi, Prince, and Marland (2000) indicate that three primary stages exist within this process when considering a corn-based origin: 1) the stage of "milling" ("dry or wet") and "hydrolysis," 2) the stage of "yeast fermentation," and 3) the stage of "distillation."

Historically, the United States (U.S.) commenced subsidizing the implementation of ethanol products as an automobile fuel during 1978 (Gardner, 2007). According to the writings of Gardner (2007), this U.S. national subsidization is the result of the "1970s disruptions in petroleum supplies from the Middle East," and such subsidization manifests "tax credits to energy companies as opposed to payments to ethanol producers." Runge and Senauer (2007) confirm the historical instigation of corn-based ethanol as an "alternative fuel" resulting from the "oil embargo imposed by the Organization of Petroleum Exporting Countries" (OPEC). Individual states within the U.S. also demonstrate various forms of subsidies. According to the writings of Gardner (2007), the state of Iowa manifests a form of subsidization through "tax benefits related to state motor fuel taxes and financial incentives for investment in ethanol plants." The prominence of corn-based bio-fuel, resulting from such subsidies, is also confirmed by the writings of Runge and Senauer (2007). Patzek (2004) indicates that approximately " $20 \%$ of U.S. corn production" contributes to the production of bio-fuel. Based on these observations, evidence is presented that suggests a national demand for such fuel products has existed for nearly four decades within the U.S.

During the late 1970s and during the 1980s, additional legislation occurred that impacted ethanol production within the U.S. (Agricultural Market, 2006). The U.S. Energy Tax Act of 1978 provided a variety of "excise tax exemptions" regarding ethanol fuel blends. The period of the 1980s witnessed the introduction of "alternative blenders' credit" with respect to varying amounts of ethanol product contained within fuel mixes (Agricultural Market, 2006). During the 1990s, an increase in the demand for such fuel was demonstrated within the U.S. This increased demand resulted from legislation related to the Clean Air Amendments via the "mandates for the use of oxygenates as gasoline additives as a means to improve air quality in certain urban areas (Gardner, 2007). Additional legislation that impacted the increased demand requirements of the 1990s also included the considerations of U.S. legislation associated with renewable fuel standards (Gardner, 2007). According to the writings of Gardner (2007), the 2007 requirements affiliated with such domestic, U.S. renewable fuel standards indicate that "7.5 billion gallons of fuel from renewable sources" must be expended as "transportation fuel" before the year 2012. Such requirements of demand further contribute to the observations of Fulton (2005) with respect to the global estimates of bio-fuel comprising five percent of global transport fuel consumption before the year 2010. 
Additional, contemporary events also contribute toward the increased demand for bio-fuel products. These considerations include a reduction in the U.S. demand for methyl tertiary butyl ether (MTBE) and various, recent increases in oil prices. The reduction in U.S. demand for MTBE occurred as a result of environmental and liability issues associated with its "toxicity and persistence in soil or water when spilled (Gardner, 2007)." Because of these environmental and liability issues, the writings of Gardner indicate that twenty states within the U.S. "banned MTBE as a fuel additive" between 2001 and 2005. As a result, an increase in the demand for ethanol was manifested because of the oxygenate potential of ethanol within fuel mixes. This notion is confirmed by the writings of Gardner (2007).

Increases among recent oil prices also contribute to the demand for ethanol. These increases among oil prices contributed to the recent, increased status demands of ethanol primarily as a bio-fuel and secondly as an oxygenate component of fuel. The prominence of corn-based bio-fuel, resulting from such increased oil prices, is also confirmed by the writings of Runge and Senauer (2007). These notions are also confirmed by the writings of Gardner (2007). As a result of expansions to accommodate the needs associated with such increased ethanol demands, the writings of Gardner (2007) indicate that the U.S. capacity for production increased significantly after the year 2000. This increased capacity for production is estimated to satisfactorily process product quantities that are double the observed 2006 amounts of " 4.9 billion gallons" of ethanol product (Gardner, 2007). With respect to the 2005 global bio-fuel production quantities, Runge and Senauer (2007) indicate that U.S., corn-based ethanol contributed " 44.5 percent" of the " 9.66 billion gallons" globally. Therefore, based on these observations of growth, evidence is presented to suggest that a significant demand exists for corn-based ethanol and bio-fuel.

Despite such promise as an alternative energy source, the various growth potentials, barriers, and financial costs and benefits associated with corn-based ethanol and bio-fuel must be considered with respect to potential growth during upcoming decades. The anticipated growth and barriers associated with bio-fuels may be considered from the perspective of the economic contemplation of allocating scarce resources to satisfy the unlimited human wants and needs of a market. Therefore, the basic concepts of supply versus demand are relevant. Such characteristics may demonstrate various economic concerns during the considered period between the present time and the year 2030. The growth potential of bio-fuels as an alternative source of energy may be considered from a variety of perspectives. Timmins (2006) advocates bio-fuels as a renewable source of energy. The writings of Dahl (2004) consider the potential of such an alternative if "fossil fuels get scarcer and worries of global climate change continue."

According to Sims, et. al., (2006) growth potential is manifested through the "need of countries to substitute for imported coal, oil, and gas with a locally produced fuel to either ensure security of supply or to improve trade balances." Within the U.S., a contributor to bio-fuel expansion is the "decline in crude oil reserves and production rates, and its increasing dependency of oil imports (Sims, et. al., 2006)." Global contributors toward the expansion of bio-fuel potentials include "industrialization of South East Asia and Brazil," and the increasing rate of industrialization within "China and India (Sims, et. al., 2006)." Gardner (2007) considers the increases in the price of oil and "investment incentives" (e.g., ethanol and corn production subsidies) associated with the development of ethanol plants as contributors toward bio-fuel growth. Runge and Senauer (2007) confirm these aspects of oil pricing and subsidization as contributors toward the growth of bio-fuels. Further, various governments advocate the investigation and development of bio-fuels as alternatives "for finite supplies of oil-based fuels that currently dominate motor vehicle transportation," as methods of improving "energy security," and of decreasing environmental and atmospheric pollutants (Agricultural Market, 2006). Based on these observations, various research and development (R\&D), commercial, policy, and regulatory influences exist with respect to the growth potential of corn-based bio-fuel and ethanol.

According to Gurgel, Reilly, and Paltsev (2007), this economic allocation of bio-fuel resources demonstrates the balancing of energy issues versus human food issues because of the potential of bio-fuels to act as substitutes and complements for "fossil fuels." The result of using corn crops for fuel, instead of food, generates a competition for crop and land resources that impacts "food prices" and causes "additional pressure for deforestation (Gurgel, Reilly, and Paltsev, 2007)." This competition increases prices of the agricultural ingredient globally, and have adverse "consequences for poorer consumers (Gurgel, Reilly, and Paltsev, 2007)." Further, as a result of the "ethanol expansion in the U.S.," the price of corn demonstrated a "70\% increase" between the years of 2005 and 
2007 (Gurgel, Reilly, and Paltsev, 2007). Naylor, et. al., (2007), also emphasizes the constraints that are associated with "land area and yield potential," and consider the effect of "price feedback" limitations with respect to land area crop substitutions. Based on these considerations, this competitive relationship demonstrates potential barriers for the growth of bio-fuel that may impact R\&D and commercial enterprise.

Such limitations are not the sole considerations of barriers that may influence the growth potentials of biofuels. Additional barriers may include the "high demand for water and nutrients" necessitated by agricultural needs, difficulties of "conversion plants" to achieve necessary "economies of scale," various finance and contract negotiations, weather and geographic "suitability" conditions, atmospheric carbon effects, various "trade reforms" and government subsidy considerations, and "power generation and distribution infrastructure (Sims, et. al., 2006)." Infrastructure limitations also include the inability of bio-fuel to be "blended" among existing refineries and "batched through existing pipelines (EIA, 2008a)." These infrastructure limitations are exacerbated because the distribution of such bio-fuel must occur through the use of "railroad cars and tanker trucks made from bio-fuel compatible materials (EIA, 2008a)." Each of these considerations demonstrates potential R\&D, commercial enterprise, and policy and regulatory barriers that may impact bio-fuel growth.

The economic and financial characteristics of bio-fuels must also be considered with respect to the perspectives of costs. Makus, Guenthner, and Foltz (2007) indicate that production costs are a primary consideration of such characteristics. The costs of operations are also salient considerations of bio-fuel initiatives. According to the United States Department of Agriculture (USDA, 2005), the "variable operating expenses include electricity, fuels, waste management, water, enzymes, yeast, chemicals, denaturant, maintenance, labor, administrative costs, and other costs." Additional, domestic operating expenses (e.g., electricity) "averaged 17.29 cents per gallon of ethanol (USDA, 2005)." Further, USDA estimates of costs associated with labor "ranged from 3 to 11 cents per gallon, and management, administration, insurance, and tax expenses from 1 to 18 cents per gallon (USDA, 2005).”

The considerations of costs versus benefits may be evaluated with respect to bio-fuels. According to Blank and Tarquin (2005), a benefit-cost (B/C) ratio may be established using the variables of cost, benefit values, and disbenefit values. Evaluation occurs according to economic acceptance or rejection criteria (Blank and Tarquin, 2005). Acceptance is recommended if the value of the $\mathrm{B} / \mathrm{C}$ ratio surpasses or is equivalent to the value of 1.0 , and rejection is recommended if the value of the $\mathrm{B} / \mathrm{C}$ ratio is less than the value of 1.0. Additional consideration may be given to the basis of mutual exclusion.

A limited set of benefit-cost analysis calculations and outcomes may be considered with respect to the values associated with cost data. The method of calculating B/C outcomes of Blank and Tarquin (2005) is used to process quantitative data. Because this paper is concerned only with the characteristics of corn-based (i.e., maize) ethanol and bio-fuels, the category of biodiesel vegetable oil is not considered within the analysis. Therefore, this set of benefit-cost analysis outcomes only includes the categories of ethanol wheat, ethanol maize (i.e., corn), sugar beet, and sugar cane. A rate of 5.2\%, as specified by Hart (2007), is incorporated to determine the financial values of annual worth associated with costs.

A conversion of liters to gallons occurred to establish a common unit of measurement. A strategic period of five years is established as a chronological basis of investigation. The pricing data of international fuels were obtained from the U.S. Energy Information Administration (EIA, 2008b) and Motortrends. The B/C method applied to mathematically process the data sets conforms to the formulae described by Blank and Tarquin (2005). The accompanying spreadsheet file demonstrates the mathematical formulas, calculations, and outcomes that are necessary for determining $\mathrm{B} / \mathrm{C}$ outcomes and evaluations among alternatives. A total of four $\mathrm{B} / \mathrm{C}$ investigations were performed with respect to the given data because of the scope and magnitude of this paper. Within this paper, comparisons are provided with respect to both alternative and traditional entities. U.S. corn-based ethanol (i.e., maize) is used among all calculations as a static entity. Table 1 presents the $\mathrm{B} / \mathrm{C}$ outcomes and recommended acceptances. 
Table 1: B/C Outcomes and Recommended Acceptances

\begin{tabular}{|c|c|c|c|c|}
\hline Alternative 1 & Alternative 2 & Fuel Type & B/C Ratio & Recommended Acceptance \\
\hline E.U. Wheat & U.S. Corn (Maize) & E10 & 30.00 & U.S. Corn (Maize) \\
\hline E.U. Wheat & U.S. Corn (Maize) & E85 & 254.99 & U.S. Corn (Maize) \\
\hline Brazil Sugar Cane & U.S. Corn (Maize) & E10 & 0.32 & Brazil Sugar Cane \\
\hline Brazil Sugar Cane & U.S. Corn (Maize) & E85 & 2.71 & U.S. Corn (Maize) \\
\hline Brazil Traditional & U.S. Corn (Maize) & E10 & 80.11 & U.S. Corn (Maize) \\
\hline Brazil Traditional & U.S. Corn (Maize) & E85 & -68.71 & Brazil Sugar Cane \\
\hline
\end{tabular}

Note: International fuel price data were obtained from EIA and Motortrends (2008).

Regardless of the outcomes of the benefit-cost analysis calculations, the future of corn-based ethanol and bio-fuels must be considered. Based on the aforementioned definition of ethanol per Kheshgi, Prince, and Marland (2000), the writings of Gardner (2007), the writings of Fulton (2005), and the writings of and Runge and Senauer (2007), the potential of corn-based ethanol and bio-fuel as alternative energy sources is salient with respect to both national and global energy demands. Such considerations may be examined chronologically, from a perspective that encompasses the contemporary period through the year 2030, with respect to both the global and domestic potentials of corn-based ethanol and bio-fuels.

According to the Energy Information Administration (EIA), the consumption of worldwide liquid fuels will increase to "118 million barrels" daily during the year 2030, and the greatest consumption increases are anticipated within "North America and non-OECD Asia" entities (EIA, 2007). The greatest components of these estimates are manifested among the transportation and industrial sectors.

An analysis of such future events must also consider bio-fuels with respect to the relationships of supply and demand. According to Gurgel, Reilly, and Paltsev (2007), production increases are anticipated to increase "rapidly" to achieve 221 Exajoules annually before the "end of the century." According to Kheshgi, Prince, and Marland (2000), the consumption of global energy is "expected to double" before the year 2030, and the estimated bio-fuel contributions toward the satisfaction of such "energy needs" may approach "15\%" during the year 2030. However, according to Kheshgi, Prince, and Marland (2000), such an estimate is contingent upon an efficient "global economy" that has a "lower total demand for carbon-based fuels."

According to the writings of Kheshgi, Prince, and Marland (2000), the EIA (2007), Gardner (2007), Runge and Senauer (2007), and Sims, et. al., (2006) the potential of growth for bio-fuels during this time period is feasible. Based on the global energy fuel production estimates, that are defined by the EIA (2007), with respect to the period between the years of 1980 through 2030, the relationship between competing fuel entities, and bio-fuels, indicates that bio-fuels will continue to contribute toward the satisfaction of energy needs during the considered period.

Additional considerations, with respect to future events, may be contemplated regarding the potential of bio-fuel in conjunction with the period of time leading towards the year 2030. The basic nature of the economic allocation of scare resources to satisfy human needs and wants must be considered with respect to this period. According to the writings of Gurgel, et. al., (2007), such an economic allocation of resources must also be considered from a perspective of the costs of production. Also, Gurgel, et. al., (2007) consider the salient factors of such production to be land requirements, "process energy requirements," and cost increases "relative to the existing technology" associated with the end-use output parameters of "gasoline and electricity." Within their discussions, Gurgel, et. al., (2007) contemplate relevant uses of land for the purposes of generating fuel versus land usage for the purposes of food production, within the context of the remaining factors. Based on the writings of Gurgel, et. al., (2007), there is a potential for food prices to be influenced through the diversion of corn to produce ethanol. Daschle (2007) also considers the use of corn to generate fuel versus its food use, and advocates the development of fuel. Pimental and Patzek (2006) consider the ethical and moral implications of using corn as a fuel ingredient versus its use to feed the "malnourished." Based on these writings, it is the opinion of this student that such debates will become considerably more visible, in a commensurate fashion, with the growth of the bio-fuel industry during the years leading toward 2030 . 
The economic use of land is considered among different perspectives. Patzek (2004) considers such economic resource allocation with respect to the potential survival of humanity. Land usage competition concerning food crops is also discussed by Fulton (2005). The economic potential of optimizing land use is considered by Sims, et. al., (2007) through discussions of "energy cropping," the motivations to "attract growers to change from traditional land uses," and potential changes in "market preferences." Naylor, et. al., (2007) consider the risks associated with the "sustainable development" of such crop use, the potentials of changes among "agricultural markets," and policy factors that may influence future initiatives. Based on these writings, it is the opinion of this student that the use of land, to grow and develop corn as a component of bio-fuel, will be a salient consideration both domestically and internationally during the period leading to the year 2030 .

During the period of time that precedes 2030, attention also must be given to environmental and atmospheric factors that may influence the bio-fuel industry. Naylor, et. al., (2007) indicate that bio-fuels manifest a potential to reduce "greenhouse gas" emissions because they "recycle atmospheric carbon dioxide." Pimental and Patzek (2006) indicate that the "production of corn ethanol" contributes toward "soil erosion, heavy use of nitrogen fertilizer and pesticides, and a contribution to global warming." Comis (2006) indicates that "plant-based bio-fuels, such as ethanol, significantly reduce net emissions of greenhouse gases compared to petroleum-based fuels." Nash (2007) considers the potential negative attributes of "greenhouse gases" that may result from bio-fuels. A consideration of these compositions indicates that both the writings of Comis (2006) and Naylor, et. al., (2007) contrast with both the writings of Pimental and Patzek (2006) and Nash (2007) with respect to the detrimental versus beneficial potentials of the environmental and atmospheric effects of bio-fuels. Based on these observations, it is the opinion of this student that such arguments have the potential to increasingly influence the policies and regulatory practices of nations during the growth of the bio-fuel industry prior to the year 2030.

When considering the strategic aspects of energy sources between the contemporary period and the year 2030, it must be acknowledged that alternative, competing ingredients and sources of fuel, other than corn-based and other organic sources, exist that may contribute toward the satisfaction of future energy requirements. Based on the production estimates of the EIA(2007), that are delineated within Figure 4, petroleum-based entities will continue to contribute toward the satisfaction of future energy requirements. Gurgel, et. a., (2007) also indicate that nuclear sources will contribute toward such satisfaction. With respect to the production of ethanol itself, non-corn alternatives exist that provide ingredient material for the generation of fuel. Naylor, et. al. (2007) indicate that oil palm, soy, and sugar cane provide alternatives to corn as primary ingredient alternatives. Powlson (2005) indicates that both switchgrass and wheat are alternatives toward the ingredient components of bio-fuel. Runge and Seneaur (2007) also indicate that the "ethanol industry will increasingly turn to grasses, trees, and resides from field crops, such as wheat and rice straw," in addition to corn products, as ingredient compounds of fuel generation. Sheehan, et. al., (2004) also considers natural gas as an alternative. Jones (2007) indicates that fuel cells may also contribute toward the satisfaction of future energy requirements. Timmins (2006) advocates the future use of wind and solar energies. Based on these writings, it is the opinion of this student that such alternatives may become both future complements and competitors, of the bio-fuel industry, during the period leading toward the year 2030.

\section{CONCLUSIONS AND RECOMMENDATIONS}

Based on the writings of Dahl (2004), oil-based products are a limited resource. According to Dahl (2004), human energy needs and wants are static and constant (e.g., warmth in the winter months, etc.); however, only the method of satisfying these human requirements changes through time (e.g., use of coal vs. petroleum). When taken within the context of the traditional, economic problem of allocating scarce resources to satisfy the unlimited needs and wants of humans, it is evident that alternative methods of energy must be considered with respect to the future energy requirements of humans. Given these considerations, various conclusions and recommendations may be manifested concerning the potential of bio-fuel.

Based on the aforementioned arguments and discussions regarding bio-fuel, it may be concluded that the bio-fuel industry is an evolving and maturing field of endeavor. Through time, such maturation and development will be influenced nationally and globally as non-renewable, traditional sources of energy and fuel are expended. Therefore, bio-fuel demonstrates the capacity, as a renewable source of energy, to contribute toward the future satisfaction of energy needs and requirements. However, such growth, development, and maturation are not without debate. 
Based on the aforementioned arguments, writings, and discussions regarding bio-fuel, despite its promise as an energy source, it is not the sole alternative of satisfying a significant, future energy requirement. Other entities may be viewed as either complements or competitors of bio-fuel (e.g., fuel cells, nuclear power, wind, solar, etc.). However, based on the preceding writings, many of these alternative considerations are also maturing, developing, and evolving fields. Given this consideration, it is the opinion of this student that bio-fuel may mature and develop as a potential contender among these alternatives with respect to the satisfaction of future energy requirements.

Based on the preceding discussions and arguments, it is the opinion of this student that the national and global implications of bio-fuel must be contemplated. It may be concluded that various, governmental factors (e.g., subsidies, environmental policies, land regulation, etc.) will influence the growth of the bio-fuel industry as it develops and matures. Therefore, legislation concerning the environmental and atmospheric concerns associated with bio-fuel has the potential to impact the bio-fuel industry with respect to the satisfaction of human energy requirements. Hence, governmental factors have the potential of affecting the future bio-fuel industry, both nationally and globally, as bio-fuel matures and develops as an industry.

Given the preceding discussions, arguments, and conclusions, various recommendations may be considered regarding the bio-fuel industry. It is the opinion of this student that bio-fuel should be considered as a complement to existing fuel and energy sources. Futher, it should be investigated as a method through which various levels of economies (e.g., global, national, regional, and local) may be impacted as a tool through which various economic functions are instigated. Given the differing, contrasting studies that consider the environmental and atmospheric impacts of bio-fuels, it is the opinion of this student that bio-fuel should continue to be investigated, from a variety of perspectives, as a method of satisfying future energy requirements without posing significant, human dangers. The financial implications and aspects of bio-fuel are considerable. Based on the preceding discussions concerning the financial attributes of bio-fuels and the bio-fuel industry, it is the recommendation of this student that bio-fuel investments be considered from a variety of cost and benefit perspectives with respect to potential alternatives.

Regardless of the current and future considerations that are associated with bio-fuels, it is evident that contemporary methods of satisfying human energy needs will change through time. Per the discussions of Dahl (2004), such human energy requirements are static and unchanging through time, but the methods and technologies of their satisfaction are dynamic. The potential of bio-fuel, as an energy source to satisfy a component of these human energy needs and wants may demonstrate future growth and behaviors that are commensurate with the writings of Dahl (2004). Although its promise as a source of energy is salient consideration that may impact future generations, bio-fuel should not be viewed as a solitary source of satisfaction concerning human energy needs and wants. Instead, it is the opinion of this student that bio-fuel represents a promising method of satisfying such human energy needs and wants, but should not be labeled as the solitary, dominant source of such satisfaction. It is also the opinion of this student that future times will unveil the true growth and maturation of the evolution of the bio-fuel industry because of the inability to accurately predict and forecast future events during a thirty-year period. Therefore, it is the recommendation of this student that any and all future projections that exist concerning bio-fuel are only estimates, and should be considered as indicators of the potential of bio-fuel as an energy source. Regardless, based on the preceding discussions and arguments, it is the opinion of this student that time itself will divulge the method through which the future energy needs and requirements of humans are satisfied.

\section{AUTHOR INFORMATION}

Daniel Adrian Doss, Ph.D. - Adrian is a faculty member with the University of West Alabama. His research interests include cyber-crime, economics, and finance. He also is a Lieutenant Colonel with the Mississippi State Guard where he serves within a military police unit. He resides in Saltillo, MS, and his interests include sacred harp music, reading, and college football season.

Stacy Troxel, M.S. - Stacy is a faculty member with Arkansas State University. Her research interests include nursing and education. She is a former U.S. Navy officer, and has significant experience within the nursing profession. Her interests include yoga and athleticism. 
William Sumrall, Ed.D. - Bill is a faculty member with Belhaven College. His research interests include finance and economics. Bill is a former realtor, and has a robust background as an academician. His interests also include the restoration of antique vehicles.

\section{REFERENCES}

1. Agricultural Market. (2006). Agricultural market impacts of future growth in the production of biofuels. OECD Papers, 6(1), 1-55.

2. Blank, L. and Tarquin, A. (2005). Engineering Economy. ( $6^{\text {th }}$ ed.). McGraw-Hill Publishing: New York.

3. Comis, D. (2006). Switching to switchgrass makes sense. Agricultural Research, 54(7), 19-19.

4. Dahl, C. (2004). International Energy Markets: Understanding Pricing, Policies, and Profits. PennWell Publishing: Tulsa, OK.

5. $\quad$ Daschle, T. (2007). Food for fuel? Foreign Affairs, 86(5), 157-162.

6. $\quad$ EIA. (2007). Petroleum and other liquid fuels. Energy Information Administration. Retrieved April 9, 2008 from http://www.eia.doe.gov/oiaf/ieo/pdf/oil.pdf

7. EIA. (2008a). Biofuels in the U.S. transportation sector. Energy Information Administration. Retrieved April 9, 2008 from http://www.eia.doe.gov/oiaf/analysispaper/biomass.html

8. EIA. (2008b). Weekly retail premium gasoline prices. Energy Information Administration. Retrieved April 9, 2008 from http://www.eia.doe.gov/emeu/international/gas1.html

9. Fulton, L. (2005). Biofuels for transport: A viable alternative? OECD Observer, 249, 41-35.

10. Gardner, B. (2007). Fuel ethanol subsidies and farm price support. Journal of Agricultural \& Food Industrial Organization, 5(1), 1-22.

11. Gurgel, A., Reilly, J., and Paltsev, M. (2007). Potential land use implications of a global biofuels industry. Journal of Agricultural \& Food Industrial Organization, 5(1), 1-36.

12. Hart, C. (2007). U.S. agriculture's role in the international biofuel market. Iowa State University. Retrieved April 8, 2008 from http://209.85.207.104/search?q=cache:K9_hZXajIzAJ: www.card.iastate.edu/presentations/International_Biofuels.ppt+\%22growth+rate\%22+biofuel\&hl=en\&ct=c $\underline{\operatorname{lnk} \& \mathrm{~cd}=3 \& \mathrm{gl}=\mathrm{uS}}$

13. Jones, T. (2007). The world in 2027. British Journal of Administrative Management. Apr/May (58), 1011 .

14. Kheshgi, H., Prince, R., and Marland, G. (2000). The potential of biomass fuels in the context of global climate change: Focus on transportation fuels. Annual Review of Energy \& the Environment, 25(1), 199244.

15. Makus, L., Guenthner,J., and Foltz, J. (2007). Pricing nontraditional products and services. Retrieved April 9, 2008 from http://209.85.207.104/custom?q=cache:CgM69Fln6dIJ:info.ag.uidaho.edu/

Resources/PDFs/CIS0942.pdf + cost\&hl=en\&ct=clnk\&cd=4\&gl=us

16. Motortrends. (2008). Brazil gas prices. Retrieved April 10, 2007 from http://www.motortrend.com/gas_prices/33/indiana/clay/brazil/

17. Nash, S. (2007). Decrypting Biofuel Scenarios. Bioscience, 57(6), 472-477.

18. Naylor, R. Liska, A., Burke, M., Falcon, W., Gaskell, J., Rozelle, S., and Cassman, K. (2007). The ripple effect: Biofuels, food security, and the environment. Environment, 49(9), 30-43.

19. Patzek, T. (2004). Thermodynamics of the corn-ethanol biofuel cycle. Critical Reviews in Plant Sciences, 23(6), 519-567.

20. Pimental, D., and Patzek, T. (2006). Green plants, fossil fuels, and now biofuels. Bioscience, 56(11), 875875.

21. Powlson, D., Riche, A., and Shield, I. (2005). Biofuels and other approaches for decreasing fossil fuel emissions from agriculture. Annals of Applied Biology, 146(2), 193-201.

22. Runge, C., and Senauer, B. (2007). How biofuels could starve the poor. Foreign Affairs, 86(3), 41-53.

23. Sheehan, J., Aden, A., Paustian, K., Kendrick, K., Brenner, J., Walsh, M., and Nelson, R. (2004). Energy and environmental aspects of using corn stover for fuel ethanol. Journal of Industrial Ecology, 7(3-4), 117146.

24. Sims, R., Hastings, A., Schlamadinger, B., Taylor, G., and Smith, P. (2006). Energy crops: Current status and future prospects. Global Change Biology, 12(11), 2054-2076. 
25. Timmins, L. (2006). Fuel for thought: Renewable fuels for cars and homes. Alive: Canadian Journal of Health \& Nutrition, 2006(283), 58-59.

26. USDA. (2005). USDA report number 841. United States Department of Agriculture. Retrieved April 4, 2008 from http://www.ethanolrfa.org/objects/documents/126/usdacostofproductionsurvey.pdf. 


\section{NOTES}

